\title{
Stress proteins and cross-protection by heat shock and salt stress in Bacillus subtilis
}

\author{
Uwe Völker, ${ }^{1}$ Hiltraut Mach, ${ }^{1}$ Roland Schmid ${ }^{2}$ and Michael HeCKeR ${ }^{1 *}$ \\ ${ }^{1}$ Institute of Microbiology, Ernst-Moritz-Arndt-University, O-2200 Greifswald, Germany \\ ${ }^{2}$ Department of Microbiology, University of Osnabrück, W-4500 Osnabrück, Germany
}

(Received 2 March 1992; revised 15 June 1992; accepted 18 June 1992)

\begin{abstract}
Bacillus subtilis induced a set of general stress proteins in response to a salt or heat stress. Cells subjected to a mild heat stress showed a protective response which enabled them to survive otherwise lethal temperatures (e.g. $52{ }^{\circ} \mathrm{C}$ ). In a similar way bacteria were enabled to survive toxic concentrations of $\mathrm{NaCl}$ by pretreatment with lower salt concentrations. A mild heat shock induced a cross-protection against lethal salt stress. The pretreatment of cells with low salt, however, was less effective in the induction of thermotolerance than a preceding mild heat stress. Three stress proteins were identified on the basis of their $\mathbf{N}$-terminal amino acid sequences as homologues of GroEL, DnaK and ClpP of Escherichia coli. The role of general and specific stress proteins in the induction of thermotolerance/salt tolerance and cross-protection is discussed.
\end{abstract}

\section{Introduction}

Stress proteins are involved in the adaptation of bacteria to growth-limiting conditions which are quite common in nature (Hecker \& Babel, 1988). This protective function is well established for heat shock proteins of Escherichia coli, a special group of stress proteins. These proteins are essential elements in the induction of thermotolerance, a protective response which is induced by a mild heat stress and which enables the bacteria to survive otherwise lethal temperatures (Neidhardt \& VanBogelen, 1987). In rpoH mutants of $E$. coli neither induction of heat shock proteins nor of thermotolerance occurs (Yamamori \& Yura, 1982).

Heat shock proteins are encoded by genes which need a specific sigma factor, sigma 32 , for transcription. A subset of heat shock proteins, the chaperonines like GroEL, GroES or DnaK, DnaJ and GrpE, have fundamental functions for survival at very high temperatures (Kusukawa et al., 1987; Bukau et al., 1989; Ang \& Georgopoulos, 1989). The heat shock proteins belonging to this sigma 32-dependent high-temperature regulon are, however, necessary but not sufficient for thermotolerance (VanBogelen et al., 1987). Furthermore, the protection of $E$. coli against heat stress requires $\mathrm{KatF}$, a

* Author for correspondence. Tel. (3834) 5271 App. 347; fax (3834) 883353. newly described sigma factor necessary for the expression of special genes during starvation (Lange \& HenggeAronis, 1991 a, b; McCann et al., 1991).

The high-temperature regulon of $E$. coli is one of the best-known model systems for analysing the global control of gene expression (Neidhardt \& VanBogelen, 1987). Surprisingly there is only limited information available on the structure and function of heat shock genes of Bacillus subtilis (Imanaka \& Takagaki, 1988; Hearne \& Ellar, 1989; Wetzstein \& Schumann, 1990; Wetzstein et al., 1990; Hecker \& Völker, 1990; Miller et al., 1991). However, there have been detailed studies on the physiology of stress protein synthesis triggered by environmental inducers (Richter \& Hecker, 1986; Hecker \& Richter, 1987; Hecker et al., 1987, 1988; Dowds et al., 1987; Hecker \& Völker, 1990). On the basis of these studies we proposed a distinction between general stress proteins which are induced by general growth-limiting environmental signals like salt stress, oxygen limitation, nutrient starvation or heat stress, and specific heat shock proteins whose synthesis is stimulated exclusively by heat shock (Richter \& Hecker, 1986; Hecker \& Völker, 1990).

Among the environmental inducers, salt stress may be very common, especially for soil-living bacteria like $B$. subtilis (Hecker et al., 1988). In agreement with this assumption, salt stress is a very good inducer of general stress proteins in B. subtilis (Hecker et al., 1988), but not 

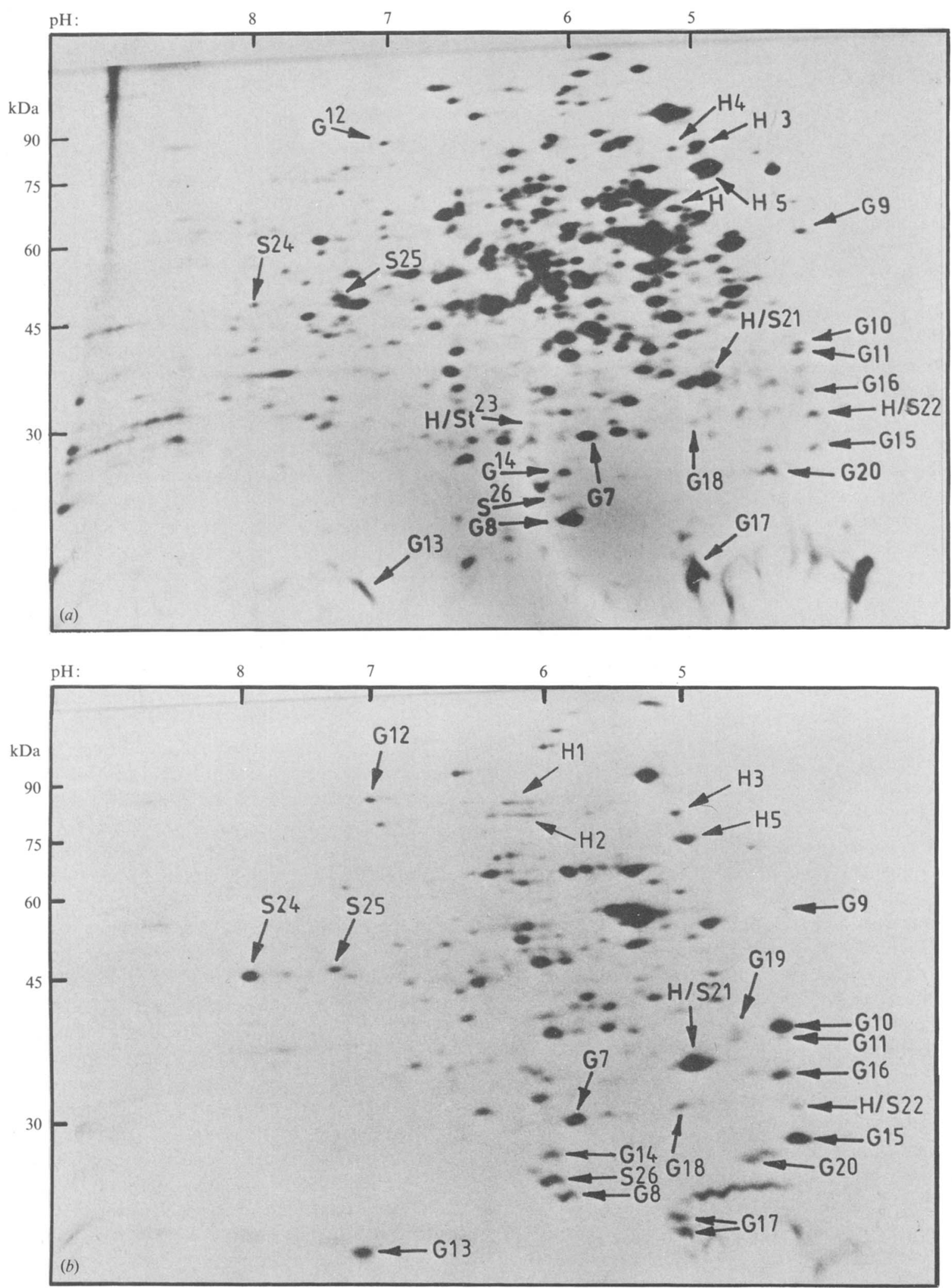

Fig. 1. Kinetics of synthesis of stress proteins in B. subtilis IS58 after salt stress. Bacteria were pulse-labelled with L-[ $\left.{ }^{35} S\right] \mathrm{methionine},(a)$ before and $(b-d)$ at different times after imposition of salt stress for $10 \mathrm{~min}(b, 10-20 \mathrm{~min} ; c, 30-40 \mathrm{~min} ; d, 60-70 \mathrm{~min})$. Cells were challenged by addition of solid $\mathrm{NaCl}$ to a final concentration of $6 \%(\mathrm{w} / \mathrm{v})$. Proteins were separated and detected as described in Methods. 

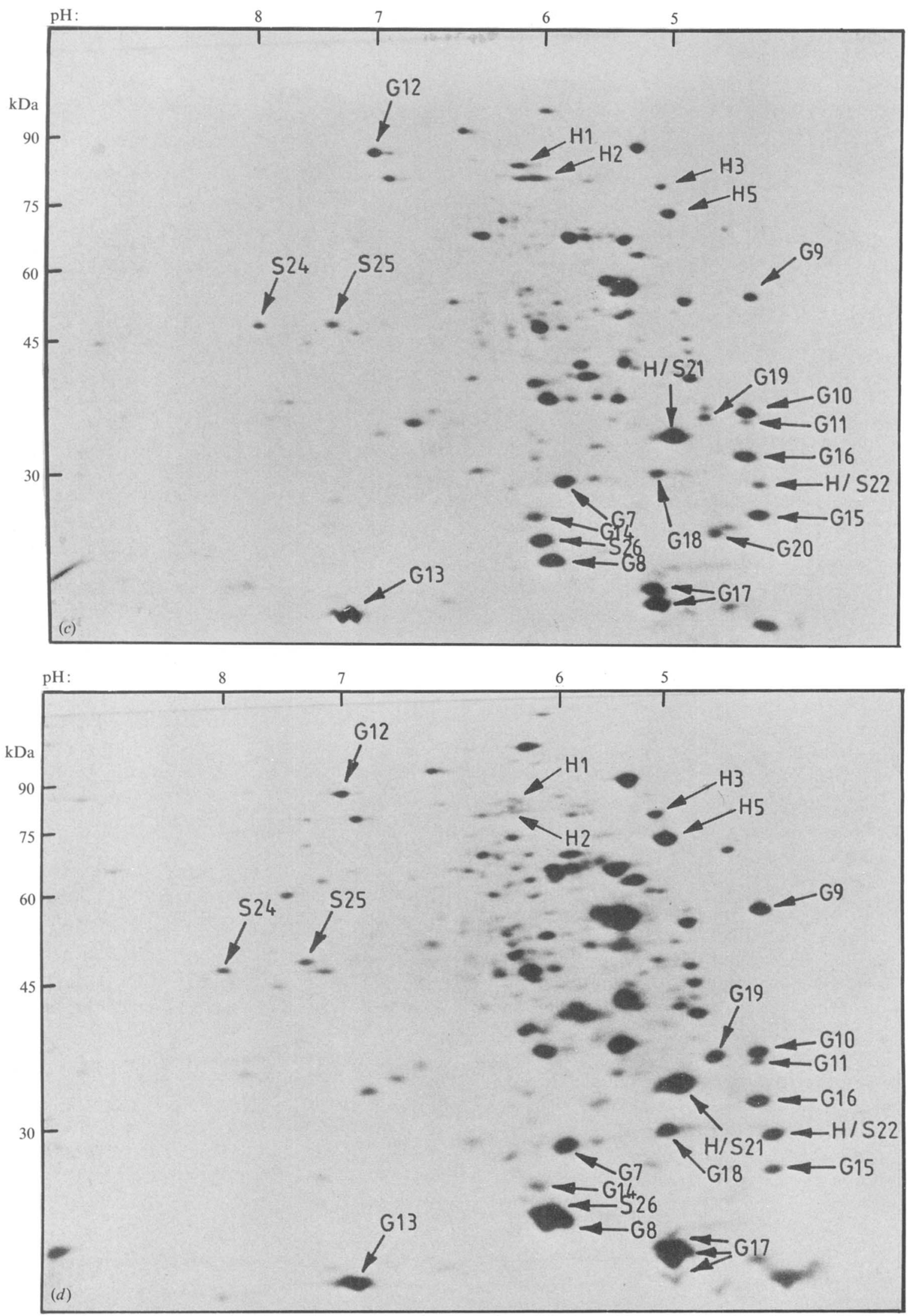
in E. coli (Clark \& Parker, 1984). Specific heat shock proteins, however, are not induced by salt stress. In this paper we describe the interaction of heat and salt stress in the induction of stress tolerance in $B$. subtilis.

\section{Methods}

Bacterial strain. The Bacillus subtilis strain IS58 (trpC2 lys; see Smith et al., 1980) was grown in a minimal medium (Belitsky \& Shakulov, 1980) as described earlier (Hecker et al., 1988).

Culture conditions/viability assay. For salt stress or heat challenge, cultures were grown at $37^{\circ} \mathrm{C}$ to a density of about $5 \times 10^{7}$ cells ml-1. At this point the cells were either treated with solid $\mathrm{NaCl}$ to a final concentration of 2,4 and $6 \%(\mathrm{w} / \mathrm{v})$, or transferred to high temperature $\left(48{ }^{\circ} \mathrm{C}, 52^{\circ} \mathrm{C}\right.$ ) for at least $4 \mathrm{~h}$. Growth was monitored by determination of $\mathrm{OD}_{500}$. Viable counts were determined by plating appropriate dilutions on agar at $37^{\circ} \mathrm{C}(2.4 \%$, w/v, agar in minimal medium $)$.

To study heat and salt resistance with and without preadaptation, exponentially growing cells $\left(5 \times 10^{7}\right.$ cells ml-1) were shifted from $37^{\circ} \mathrm{C}$ to $48^{\circ} \mathrm{C}$ for $30 \mathrm{~min}$, before being challenged either at $52{ }^{\circ} \mathrm{C}$ or with $6 \%$ $(\mathrm{w} / \mathrm{v}) \mathrm{NaCl}$ followed by testing for cell viability. In other experiments, exponentially growing cells were treated with $2 \%(w / v) ~ N a C l$ before being challenged at $52{ }^{\circ} \mathrm{C}$ or with $6 \%(\mathrm{w} / \mathrm{v}) \mathrm{NaCl}$ (final concentration). Viability of preadapted and non-adapted cells was determined by plating dilutions on agar at $37^{\circ} \mathrm{C}$.

Pulse-labelling and electrophoresis. Labelling of cellular proteins with $\mathrm{L}-\left[{ }^{35} S\right]$ methionine and separation of labelled proteins according to O'Farrell (1975) were carried out as described earlier (Hecker et al., 1988).

Microsequencing. For the determination of the N-terminal amino acid sequences, appropriate proteins were cut from 25 two-dimensional gels, electroeluted and centrifuged onto an Immobilone-membrane (Millipore). Proteins were sequenced on an Applied Biosystems A473 protein sequencer.

\section{Results}

Induction of salt tolerance by preadaptation to 'low' $\mathrm{NaCl}$ concentrations

The addition of $\mathrm{NaCl}$ to exponentially growing cells of $B$. subtilis induced general stress proteins, whereas specific heat shock proteins (e.g. H3, H5) were not induced (Hecker et al., 1988; Fig. 1). General stress proteins were synthesized with very high intensity immediately after the addition of $\mathrm{NaCl}(6 \%, \mathrm{w} / \mathrm{v})$. Most of the general stress proteins have a low molecular mass. Time-course studies revealed that this induction of stress proteins was maintained for at least $60 \mathrm{~min}$. The rate of synthesis of some of them (e.g. proteins G9, G17, G8; Fig. 1) increased after the initial induction phase. Besides general stress proteins, salt-specific proteins were also induced (e.g. proteins S24, S25 in Fig. 1). Interestingly, after a strong salt stress $(6 \%, \mathrm{w} / \mathrm{v}, \mathrm{NaCl}$ final concentration) two proteins $(\mathrm{H} 1, \mathrm{H} 2)$, first grouped as specific heat shock proteins (Hecker et al., 1988), were transiently

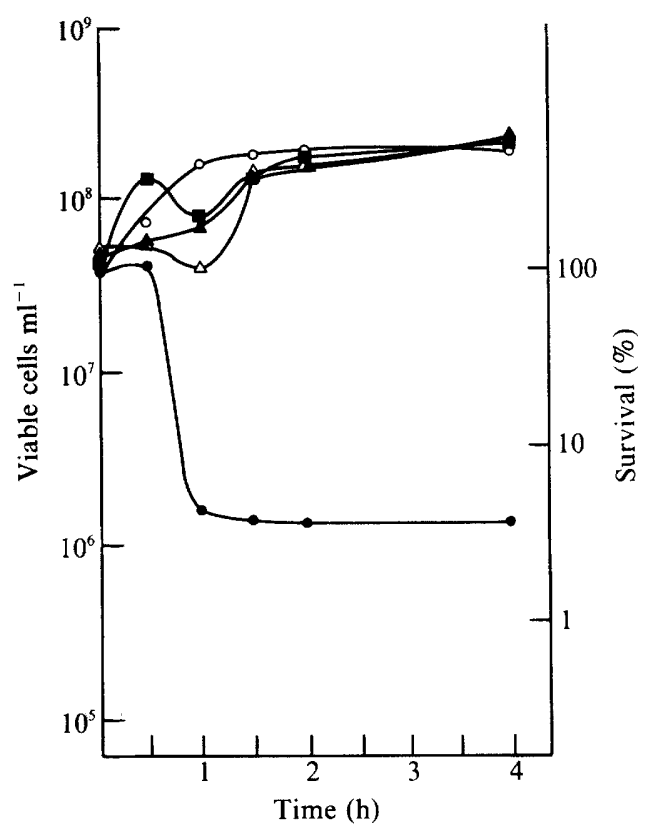

Fig. 2. Growth and viability of $B$. subtilis cells before and after salt stress. Cultures were grown to an $\mathrm{OD}_{500}$ of $\left.0.5\left(5 \times 10^{7} \text { cells ml-1 }\right)^{-1}\right)$ and challenged with $\mathrm{NaCl}(\triangle, 2 \%, w / v ; \triangle, 4 \%, w / v ; \odot, 6 \%, w / v)$. In the preadaptation experiment $(\square)$ solid $\mathrm{NaCl}$ was added (final concentration $6 \%, w / v)$ after 30 min treatment with low salt $(2 \%, w / v)$. Control cells were not stressed $(O)$. Viability was determined by plating dilutions on agar. Survival of $100 \%$ is equivalent to $5 \times 10^{7}$ cells ml ${ }^{-1}$ in this and subsequent figures. For details see Methods.

induced. However, in these earlier experiments cells were treated with $4 \%(\mathrm{w} / \mathrm{v}) \mathrm{NaCl}$ only.

The viability of cells drastically decreased after addition of $6 \%(\mathrm{w} / \mathrm{v}) \mathrm{NaCl}$. However, after pretreatment with a low salt concentration for $30 \mathrm{~min}$ and addition of the remaining $4 \%(\mathrm{w} / \mathrm{v}) \mathrm{NaCl}$ after this preadaptation period to reach the final concentration of $6 \%(\mathrm{w} / \mathrm{v}), B$. subtilis cells survived the otherwise lethal treatment (Fig. 2). The pretreatment with low salt also induced stress proteins (Fig. 3).

\section{Thermotolerance and preadaptation to a lethal temperature}

Cells of B. subtilis IS58 cannot survive the temperature of $52^{\circ} \mathrm{C}$. However, cells exhibited a markedly enhanced survival at $52^{\circ} \mathrm{C}$ after a 30 min preadaptation period at $48^{\circ} \mathrm{C}$ (Fig. 4). During this short preadaptation period heat shock proteins were produced (Fig. 5; see Richter \& Hecker, 1986).

\section{Induction of salt tolerance or thermotolerance by cross- protection experiments}

A mild heat stress $\left(30 \mathrm{~min}\right.$ at $\left.48^{\circ} \mathrm{C}\right)$ was very effective in the induction of tolerance against otherwise lethal salt 

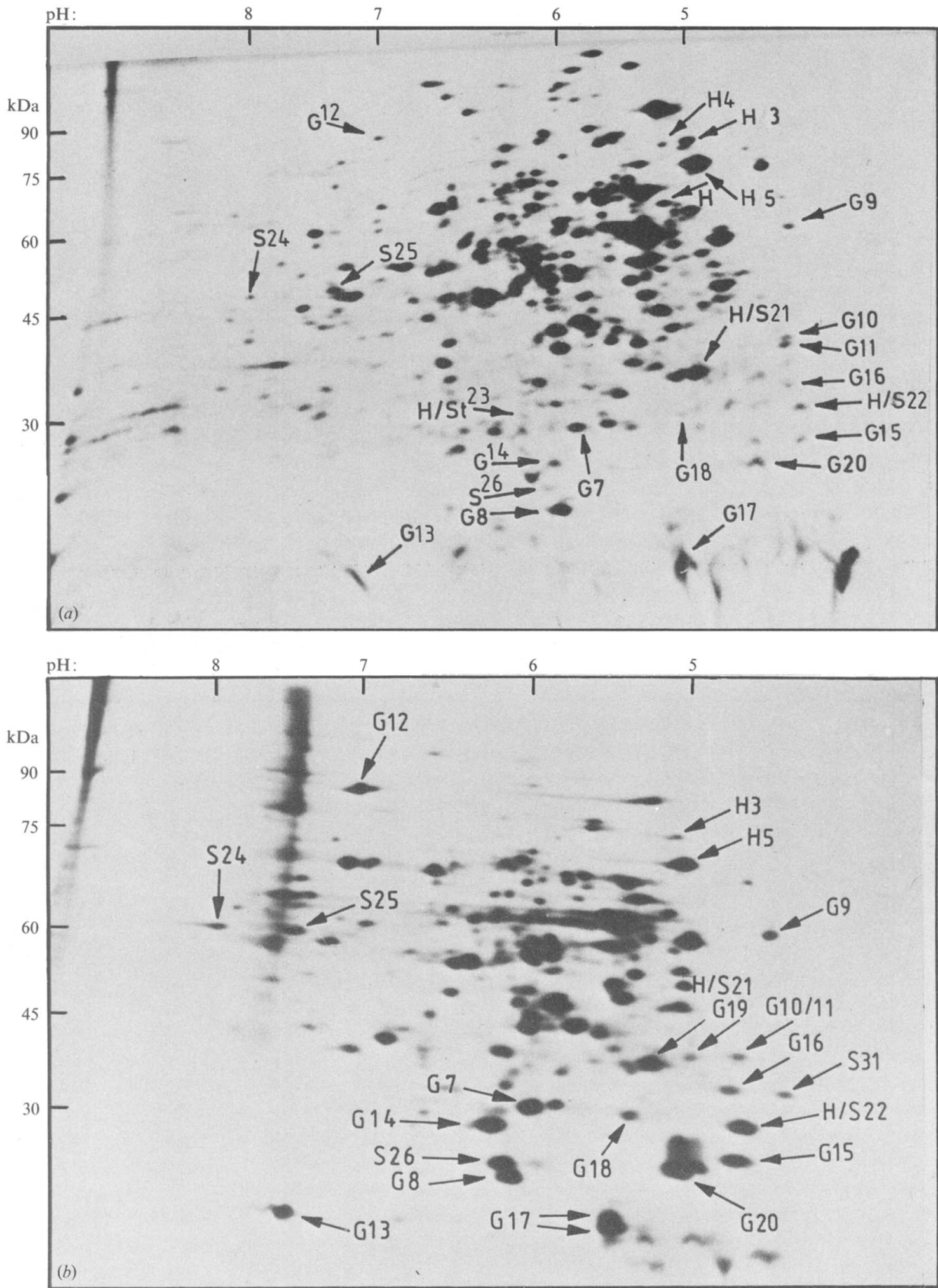

Fig. 3 (continued overleaf). Synthesis of stress proteins after imposition of salt stress with $2 \%$ (w/v) or $4 \%$ (w/v) $\mathrm{NaCl}$ and after preadaptation with low salt. In the preadaptation experiment, solid $\mathrm{NaCl}(6 \%$, w/v, final concentration) was added 30 min after treatment with $2 \%(\mathrm{w} / \mathrm{v}) \mathrm{NaCl}$. Bacteria were pulse-labelled $(a)$ before and $(b, c) 10 \mathrm{~min}$ after imposition of salt stress $(b, 2 \%, \mathrm{w} / \mathrm{v}, \mathrm{NaCl}$; $c ; 4 \%, w / v, \mathrm{NaCl})$. In the preadaptation experiment $(d)$, bacteria were labelled 10 min after raising the concentration of $\mathrm{NaCl}$ to $6 \%$ $(\mathbf{w} / \mathbf{v})$. 

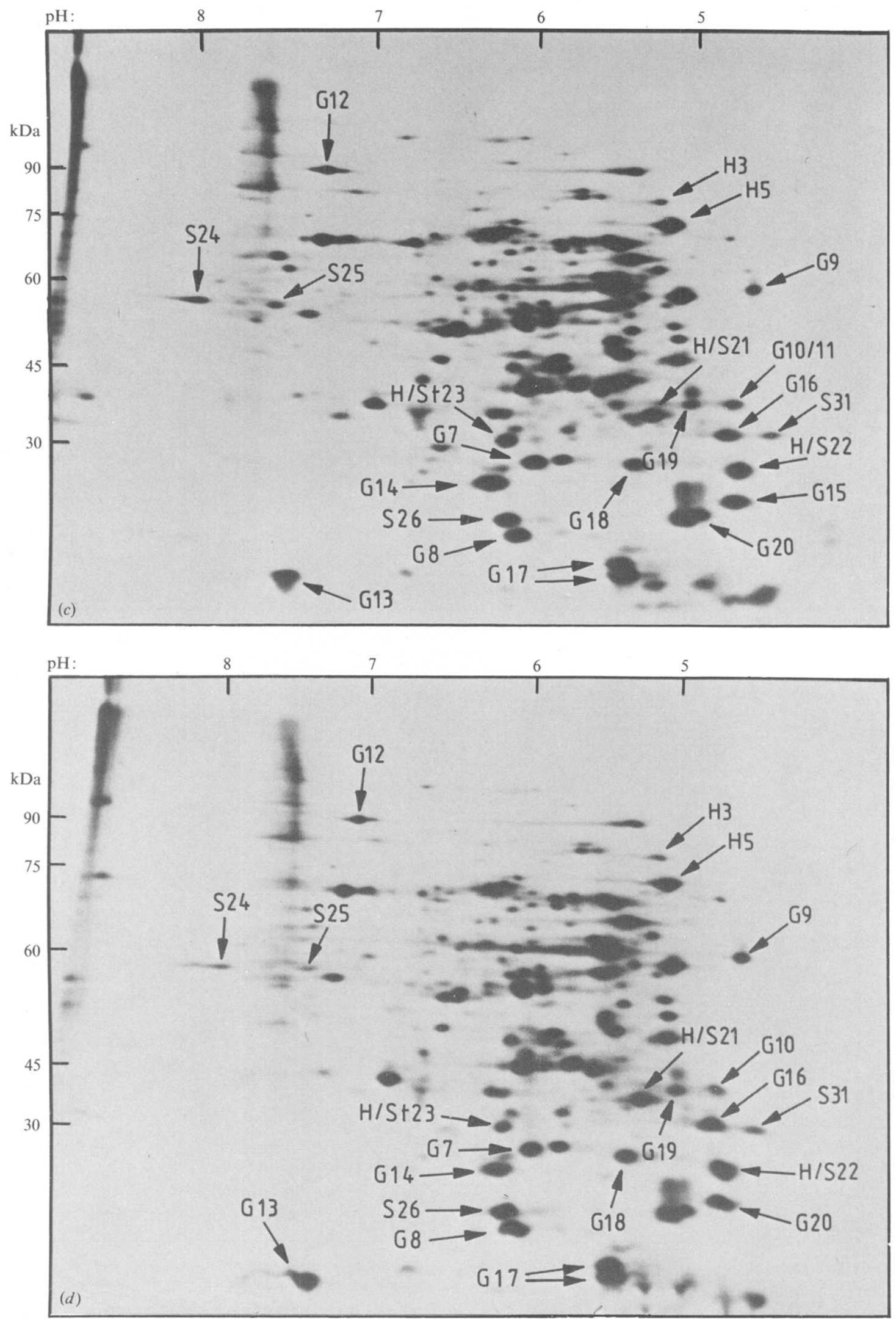


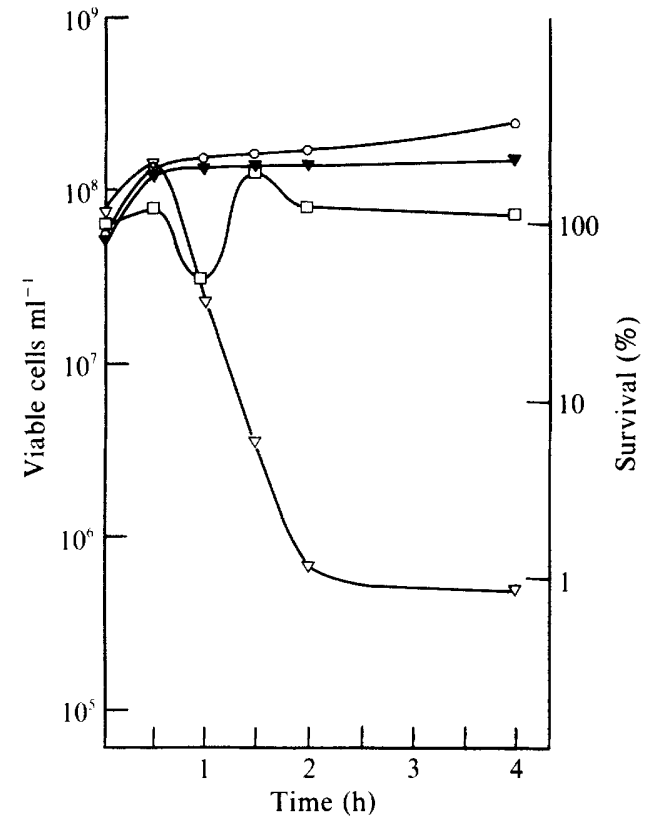

Fig. 4. Growth and viability of $B$. subtilis during heat stress. Exponentially growing bacteria were cultivated at $37^{\circ} \mathrm{C}(O)$ or shifted to $48{ }^{\circ} \mathrm{C}(\nabla)$ and $52^{\circ} \mathrm{C}(\nabla)$ or preadapted for $30 \mathrm{~min}$ at $48^{\circ} \mathrm{C}$ and then transferred to $52^{\circ} \mathrm{C}(\mathbb{Q})$. For details see Methods and the legend of Fig. 2.

concentrations (Fig. $6 a$ ). A preadaptation to the lower salt concentration $(4 \%, w / v)$ conferred only a partial protection against the lethal temperature of $52{ }^{\circ} \mathrm{C}$ (Fig. 6b).

\section{Identification of two heat-specific stress proteins and one general stress protein}

Since specific and general stress proteins seemed to be involved in the induction of stress tolerance, the $\mathrm{N}$ terminal amino acid sequences of several stress proteins were determined as described in Methods. For three of the partially sequenced proteins, the heat-specific stress proteins $\mathrm{H} 5$ and $\mathrm{H} 3$ and the general stress protein $\mathrm{G} 7$, a homology search revealed strong homology with GroEL, DnaK and ClpP of E. coli, respectively (Fig. 7). For H3 and $\mathrm{H} 5$ the $\mathrm{N}$-terminal amino acid sequences are in agreement with the data deduced from the DNA sequences of the dnaK locus and the groESL operon of $B$. subtilis (Wetzstein et al., 1992; Schmidt et al., 1992). G7, the ClpP homologue of $B$. subtilis, is missing the first 13 amino acids of the ClpP protein of $E$. coli.

\section{Discussion}

Natural growth-limiting conditions, very common in nature, induce general stress proteins. In $B$. subtilis the same stress proteins are induced by a diverse range of stresses such as heat, ethanol, hydrogen peroxide, high salt concentration, starvation for carbon or nitrogen sources, and oxygen limitation. It is tempting to speculate that these stress proteins may provide a general protection of the cell under adverse environmental conditions, but definitive evidence is still lacking. Besides these general stress proteins, all extracellular signals analysed in our studies induced a set of stressspecific proteins that may exert a specific protection against this signal and not against the others (e.g. osmotic stress - accumulation of osmoprotective substances; nutrient starvation - induction of proteins which can utilize alternative nutrient sources, etc.; see Hecker \& Völker, 1990).

According to this general scheme, heat stress induced general stress proteins as well as specific heat shock proteins. The proteins $\mathrm{H} 3$ and $\mathrm{H} 5$, identified as DnaK and GroEL, belong to this group of specific heat shock proteins (Hecker \& Völker, 1990). Salt stress induced not only some salt-specific proteins but also general stress proteins, although GroEL and DnaK were not induced. There is some evidence for a role of GroEL and DnaK in the growth and survival of $E$. coli at high temperatures (Kusukawa \& Yura, 1988). However, definitive data on the function of stress proteins in the protection against 'physiological' stress are rare (Jenkins et al., 1990, 1991; Meury \& Kohiyama, 1991).

Preadaptation to a lethal thermal shock can be achieved by a pretreatment with a mild heat stress. The same is true for salt stress. Cells were enabled to survive toxic concentrations of $\mathrm{NaCl}$ by pretreatment with lower salt concentrations which induced general stress proteins. This finding might be taken as preliminary evidence that the function of at least some stress proteins is to protect the cells from damage by either lethal heat shock or lethal salt stress. However, the role of general stress proteins and of stress-specific proteins in the induction of thermotolerance or salt tolerance needs further investigation. As a first attempt to analyse this problem we studied the induction of stress tolerance by cross-protection experiments to determine whether a mild heat stress which did not induce salt-specific stress proteins provided a tolerance against lethal salt concentrations and vice versa. Cross-protection experiments with starving $E$. coli cells have been carried out by Matin and co-workers (Jenkins et al., 1988, 1990, 1991; Matin, 1991), who found a starvation-induced cross-protection against other stresses.

$B$. subtilis cells incubated under toxic salt stress were killed more slowly if they had previously been subjected to either a mild salt stress or to a mild heat shock. Both pretreatments were similarly effective. These results may indicate that salt-specific stress proteins play an inessential role at least in this initial phase of salt tolerance. 

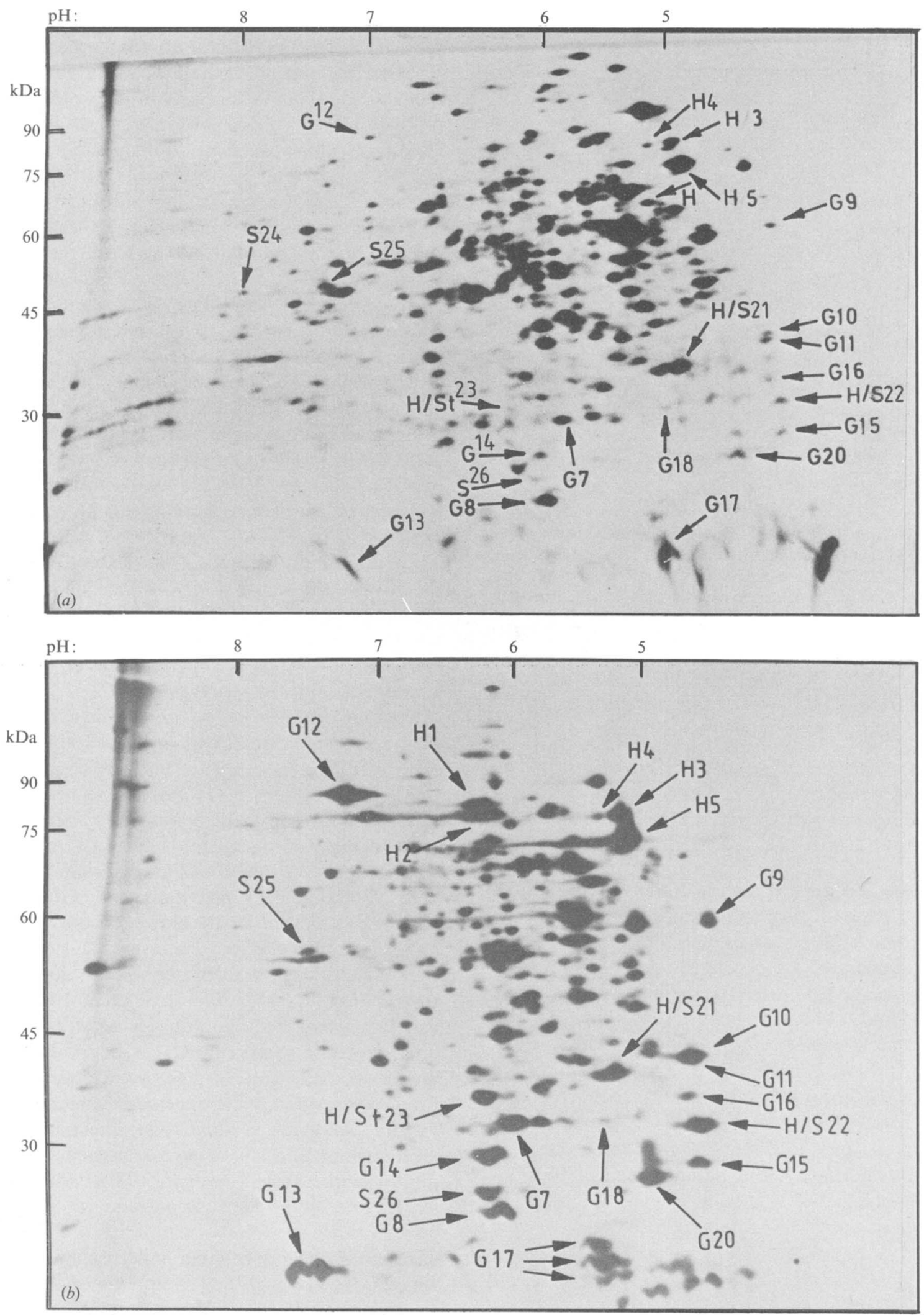

Fig. 5. Synthesis of stress proteins after heat stress and after the heat preadaptation. In this experiment the cells were preadapted for $30 \mathrm{~min}$ at $48^{\circ} \mathrm{C}$ and then transferred to $52^{\circ} \mathrm{C}$. Pulse-labelling was carried out $(a)$ before and $(b-d) 10$ min after the imposition of the final heat stress $\left(b, 48^{\circ} \mathrm{C} ; c ; 52^{\circ} \mathrm{C} ; d, 48-52^{\circ} \mathrm{C}\right)$. 

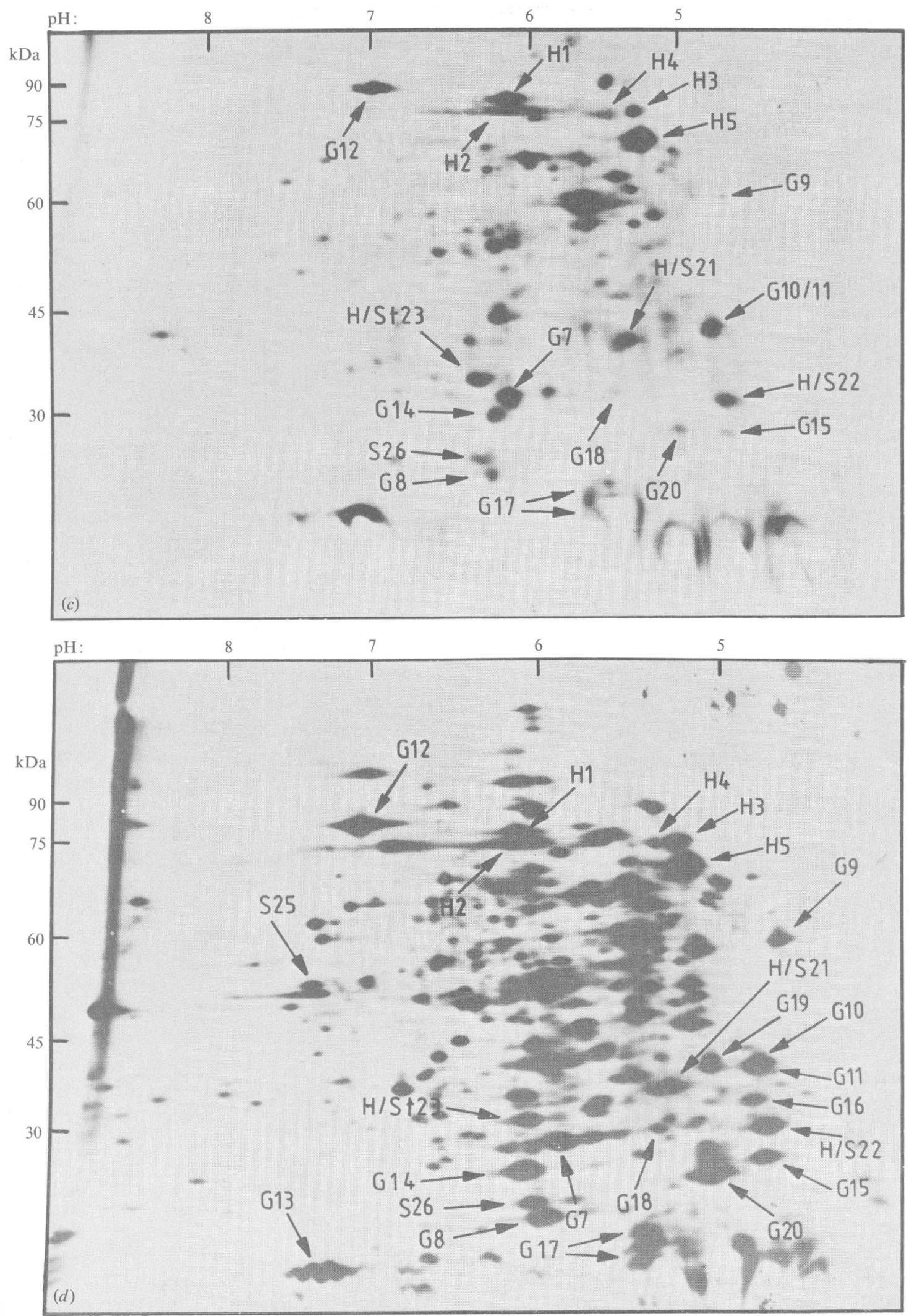

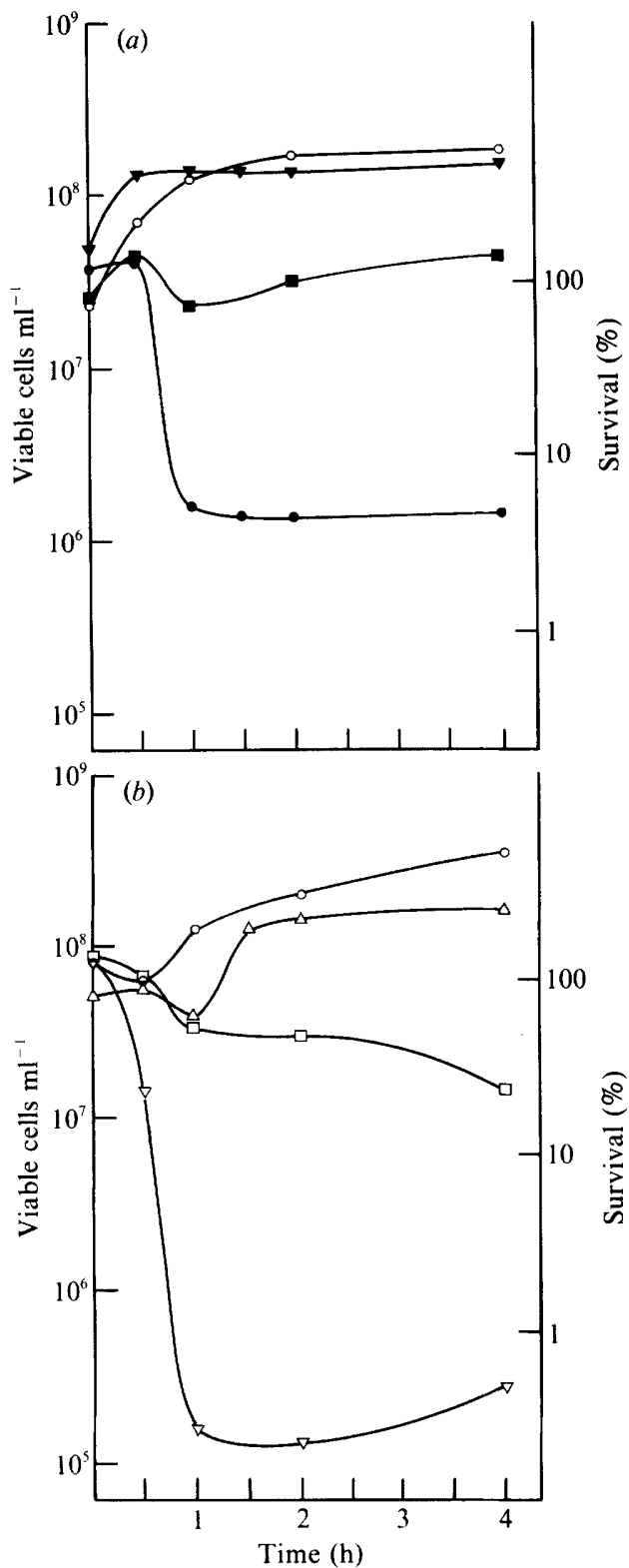

Fig. 6. Growth and viability of $B$. subtilis cells after (a) temperaturemediated salt tolerance and $(b)$ salt-mediated thermotolerance. Cultures were grown at $37^{\circ} \mathrm{C}(\mathrm{O})$ to an $\mathrm{OD}_{500}$ of $0 \cdot 5$. (a) Viability was determined either after addition of solid $\mathrm{NaCl}$ to a final concentration of $6 \%(\mathrm{w} / \mathrm{v})(\mathcal{O})$ or after temperature shift up to $48^{\circ} \mathrm{C}(\boldsymbol{\nabla})$. For the determination of cross-protection, exponentially growing cells were shifted for $30 \mathrm{~min}$ to $48^{\circ} \mathrm{C}$ and solid $\mathrm{NaCl}$ (final concentration $6 \%$, $\mathrm{w} / \mathrm{v}$ ) was added after this preadaptation period ( $\boldsymbol{G})$. (b) Viability was determined either after addition of solid $\operatorname{NaCl}(4 \%, w / v)(\triangle)$ or after a temperature shift up to $52{ }^{\circ} \mathrm{C}(\nabla)$. For cross-protection, cells treated with $\mathrm{NaCl}\left(4 \%\right.$, w/v, final concentration) for $30 \mathrm{~min}$ at $37^{\circ} \mathrm{C}$ were shifted to $52^{\circ} \mathrm{C}(\square)$.

By contrast, the pretreatment of cells with non-toxic salt concentrations was less effective in the induction of thermotolerance than a preceding mild heat shock. This result might be explained by the failure of full induction

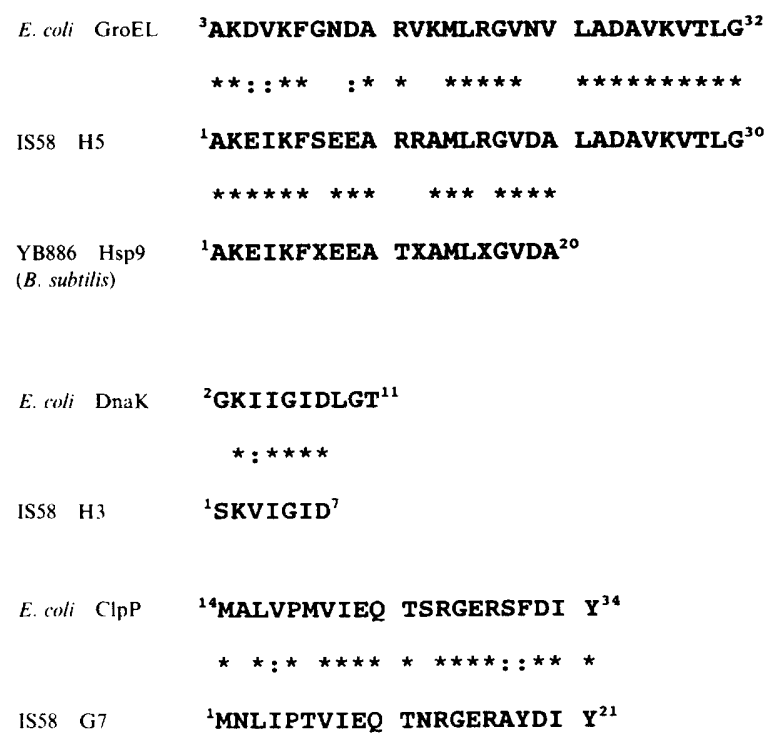

Fig. 7. Sequence alignment of the $\mathrm{N}$-terminal sequences of the $\mathrm{H} 5, \mathrm{H} 3$ and G7 proteins of B. subtilis IS58 with their protein homologues. Amino acids are given in the standard one-letter code. Identical amino acids and conservative amino acid replacements are indicated by stars and colons, respectively. Numbers define the position of the residues in the complete protein. Sequence alignments: H5 aligned with $E$. coli GroEL (Hemmingsen et al., 1988) and B. subtilis YB886 Hsp9 (Miller $\boldsymbol{e t}$ al., 1991); H3 aligned with E. coli DnaK (Bardwell \& Craig, 1984); G7 aligned with E. coli ClpP (Maurizi et al., 1990).

of specific heat shock proteins like GroEL or DnaK which may be essential for thermotolerance. Nevertheless, the different survival behaviour in pretreated and non-treated cells suggests an involvement of general stress proteins in the induction of thermotolerance and cross-protection.

The investigation of defined mutants in genes encoding general and specific stress proteins will provide exact information on the role of single stress proteins in stress tolerance. The genes coding for GroEL and DnaK have been cloned by Schumann and co-workers (Schmidt $e t$ al., 1992; Wetzstein et al., 1992). In the work described here these proteins have been localized on two-dimensional protein gels; mutants defective in these proteins will be studied in further experiments. Furthermore, we are currently cloning the gene encoding ClpP of $\boldsymbol{B}$. subtilis using oligonucleotides deduced from the $\mathrm{N}$ terminal amino acid sequence of the protein.

This work was supported by a grant from the Alexander-vonHumboldt-Stiftung to U.V. and from the Fonds der Chemischen Industrie to M.H. We thank K. H. Altendorf for his support.

\section{References}

ANG, D. \& Georgopoulos, C. (1989). The heat-shock-regulated grpE gene of Escherichia coli is required for bacterial growth at all temperatures but is dispensable in certain mutant backgrounds. Journal of Bacteriology 171, 2748-2755. 
Bardwell, J. C. A. \& Craig, E. J. (1984). Major heat shock gene of Drosophila and the Escherichia coli heat-inducible dnaK gene are homologous. Proceedings of the National Academy of Sciences of the United States of America 81, 848-852.

Belitsky, B. R. \& Shakulov, R. S. (1980). Amount of guanosine polyphosphate and the level of stable RNA synthesis in Bacillus subtilis upon inhibition of protein synthesis. Molekularnaja Biologia 14, 1343-1353.

Bukau, B., Donelly, C. E. \& Walker, G. C. (1989). DnaK and GroE proteins play roles in $E$. coli metabolism at low and intermediate temperatures as well as at high temperatures. In: Stress-induced Proteins, pp. 27-36. New York: Alan R. Liss.

Clark, D. \& Parker, J. (1984). Proteins induced by high osmotic pressure in Escherichia coli. FEMS Microbiology Letters 25, 81-83.

Dowds, B. C. A., MurPhy, P., MCConnell, D. J. \& Devine, K. M. (1987). Relationship among oxidative stress, growth cycle, and sporulation in Bacillus subtilis. Journal of Bacteriology 169, 57715775 .

Hearne, C. M. \& Ellar, D. J. (1989). Nucleotide sequence of a Bacillus megaterium gene homologous to the dnaK gene of Escherichia coli. Nucleic Acids Research 17, 8373.

HeCKer, M. \& BABEL, W. (editors) (1988). Physiologie der Mikroorganismen. Jena \& Stuttgart: VEB Gustav Fischer Verlag.

HeCKer, M. \& RICHTER, A. (1987). Physiologische Untersuchungen zur Bildung von Hitzeschockproteinen in Bacillus subtilis. Journal of Basic Microbiology 27, 253-261.

HECKER, M. \& VöLKER, U. (1990). General stress proteins in Bacillus subtilis. FEMS Microbiology Ecology 74, 197-214.

HeCKer, M., Richter, A., SChroeter, A., Wölfel, L. \& MaCh, F. (1987). Synthese von Hitzeschockproteinen nach einer Aminosäureund Sauerstofflimitation in Bacillus subtilis relA $\mathrm{A}^{+}$und relA-Stämmen. Zeitschrift für Naturforschung 42c, 941-947.

HeCKER, M., HeIM, C., VöLKER, U. \& WÖLFEL, L. (1988). Induction of stress proteins by sodium chloride treatment in Bacillus subtilis. Archives of Microbiology 150, 564-566.

Hemmningsen, S. M., Woolford, C., Van der VRies, S., Tilly, K., Dennis, D. T., Georgopoulos, C. P., Hendrix, R. W. \& Ellis, R. J. (1988). Homologous plant and bacterial proteins chaperone oligomeric protein assembly. Nature, London 333, 330-334.

ImanaKa, T. \& TAKAGaKI, K. (1988). Cloning in Bacillus subtilis of temperature-dependent promoter fragments from Bacillus stearothermophilus and Bacillus subtilis. FEMS Microbiology Letters 52, 103108.

Jenkins, D. E., Schultz, J. E. \& Matin, A. (1988). Starvation-induced cross protection against heat or $\mathrm{H}_{2} \mathrm{O}_{2}$ challenge in Escherichia coli. Journal of Bacteriology 170, 3910-3914.

Jenkins, D. E., Chaisson, S. A. \& Matin, A. (1990). Starvationinduced cross protection against osmotic challenge in Escherichia coli. Journal of Bacteriology 172, 2779-2781.

Jenkins, D. E., Auger, E. A. \& Matin, A. (1991). Role of RpoH, a heat shock regulator protein, in Escherichia coli carbon starvation and survival. Journal of Bacteriology 173, 1992-1996.

Kusukawa, N. \& YURA, T. (1988). Heat shock protein GroE of Escherichia coli: key protective roles against thermal stress. Genes \& Development 2, 874-882.

Kusukawa, N., Mori, H., Kondo, A. \& Hiraga, S. (1987). Partitioning of the $F$ plasmid: overproduction of an essential protein for partition inhibits plasmid maintenance. Molecular and General Genetics 208, 365-372.
LANGe, R. \& Hengge-Aronis, R. (1991a). Growth-phase-regulated expression of bolA and morphology of stationary-phase Escherichia coli cells are controlled by the novel sigma factors $\sigma^{\text {s. Journal of }}$ Bacteriology 173, 4474-4481.

LANGE, R. \& HENGGE-ARONIS, R. (1991 b). Identification of a central regulator of stationary-phase gene expression in Escherichia coli. Molecular Microbiology 5, 49-59.

MatiN, A. (1991). The molecular basis of carbon-starvation-induced general resistance in Escherichia coli. Molecular Microbiology 5, 3-10.

Maurizi, M. R., Clark, W. P., Katayama, Y., Rudikoff, S., Pumphrey, J., Bowers, B. \& GotTesman, S. (1990). Sequence and structure of $C l p P$, the proteolytic component of the ATP-dependent Clp protease of Escherichia coli. Journal of Biological Chemistry 265, 12536-12545

McCanN, M. P., Kidwell, J. P. \& Matin, A. (1991). The putative sigma factor KatF has a central role in development of starvationmediated general resistance in Escherichia coli. Journal of Bacteriology 173, 4188-4194.

MeURY, J. \& KohIYAma, M. (1991). Role of heat shock protein DnaK in osmotic adaptation of Escherichia coli. Journal of Bacteriology 173, 4404-4410.

Miller, B. S., Kennedy, T. E. \& Streips, U. N. (1991). Molecular characterization of specific heat shock proteins in Bacillus subtilis. Current Microbiology 22, 231-236.

NeIDHARDT, F. C. \& VanBogelen, R. A. (1987). Heat shock response. In Escherichia coli and Salmonella typhimurium: Cellular and Molecular Biology, pp. 1334-1345. Edited by F. C. Neidhardt, J. L. Ingraham, K. B. Low, B. Magasanik, M. Schaechter \& H. E. Umbarger. Washington, DC: American Society for Microbiology.

O'FARRELL, P. H. (1975). High resolution two-dimensional electrophoresis of proteins. Journal of Biological Chemistry 250, 4007-4021.

RiCHTER, A. \& HeCKer, M. (1986). Heat-shock proteins in Bacillus subtilis: a two-dimensional electrophoresis study. FEMS Microbiology Letters 36, 69-71.

Schmidt, A., Schiesswohl, M., VöLKeR, U., HeCKer, M. \& SCHUMANN, W. (1992). Cloning, sequencing, mapping and transcriptional analysis of the groESL operon from Bacillus subtilis. Journal of Bacteriology 174, 3993-3999.

Smith, I., Paress, P., Cabane, K. \& Dubnau, E. (1980). Genetics and physiology of the rel system of Bacillus subtilis. Molecular and General Genetics 178, 271-279.

VanBogelen, R., Acton, M. A. \& NeidhardT, F. C. (1987). Induction of the heat shock regulon does not produce thermotolerance in Escherichia coli. Genes and Development 1, 525-531.

Wetzstein, M. \& SchumanN, W. (1990). Nucleotide sequence of a Bacillus subtilis gene homologous to the grpE gene of $E$. coli located immediately upstream of the $d n a K$ gene. Nucleic Acids Research 18, 1289.

Wetzstein, M., Dedio, J. \& Schumann, W. (1990). Complete nucleotide sequence of the Bacillus subtilis dnaK gene. Nucleic Acids Research 18, 2172.

Wetzstein, M., Völker, U., Dedio, J., Löbau, S., Zuber, U., Schiesswohl, M., Herget, C., Hecker, M. \& Schumann, W. (1992). Cloning, sequencing and molecular analysis of the dnaK locus from Bacillus subtilis. Journal of Bacteriology 174, 3300-3310.

YAMAMORI, T. \& YURA, T. (1982). Genetic control of heat-shock protein synthesis and its bearing on growth and thermal resistance in Escherichia coli K-12. Proceedings of the National Academy of Sciences of the United States of America 79, 790-794. 